\title{
PERANCANGAN SISTEM INFORMASI PASIEN COVID-19 MENGGUNAKAN VISUAL BASIC 2010 DI PUSKESMAS PANGHEGAR
}

\author{
Sandy Mahendra ${ }^{1 *}$, Sali Setiatin ${ }^{2}$ \\ Politeknik Piksi Ganesha Bandung, Indonesia ${ }^{1,2,3}$ \\ morissandy09@gmail.com ${ }^{1 *}$, salisetiatin@gmail.com²
}

Received: 25-09-2021

Revised : 18-10-2021

Accepted: 21-10-2021

\begin{abstract}
Abstrak
Latar Belakang: Perancangan merupakan suatu proses dalam mendesain sistem baru yang dapat menyelesaikan masalah yang dihadapi. Dimulai dari proses pengolahan data dari bahan mentah dari informasi yang dilakukan oleh seorang atau sekelompok orang yang akan menjadi masukan dari sebuah sistem informasi.Selanjutnya merancang bentuk keluaran dari sebuah sistem tersebut. Sistem informasi merupakan data yang dikumpulkan menjadi satu kesatuan yang menjadi sebuah informasi yang saling berhubungan dan saling mendukung menjadi suatu informasi yang bermanfaat bagi penerimanya.
\end{abstract}

Tujuan: Tujuan dari penelitian ini adalah membuat perancangan sistem informasi pasien COVID-19 menggunakan Visual Basic 2010 di Puskesmas Panghegar.

Metode: Metode ini menggunakan analisis kualitatif dengan pendekatan deskriptif untuk pengumpulan data yaitu melakukan observasi, wawancara tanya jawab, studi kepustakaan. dan untuk mendesain membuat rancangan informasi pasien COVID-19 menggunakan Microsoft Visual Basic 2010 dan tahapan kebutuhan sistem, desain, koding, pengujian menggunakan metode pengembangan Waterfall

Hasil: Diperlukan perancangan sistem informasi pasien COVID-19 perangkat lunak yang dibuat dapat menunjang aktivitas pelaporan data pasien terkonfirmasi COVID-19 lebih mudah dicari dan data pasien COVID-19 tersebut terinput oleh system

Kesimpulan: Perancangan sistem informasi pasien COVID19 memakai program Visual Basic 2010 dan menggunakan metode waterfall yang sudah dibuat dan dirancang mengenai data identitas pasien terkomfirmasi COVID-19, informasi klinis pasien COVID-19, informasi pemantauan pasien terkomfirmasi COVID-19, dan laporan data pasien COVID19 tersebut dapat mempermudah petugas untuk menginput, mengolah, menghasilkan data pasien terlihat di tiap kelurahan yang dinyatakan sembuh.

Kata kunci: COVID-19; microsoft visual basic 2010;

$$
\text { Perancangan. }
$$


Background: Design is a process in designing a new system that can solve the problems encountered. Starting from the processprocessing data from raw materials from information carried out by a person or group of people who will be the input of an information system.Next, design the output form of a system. Information Systems is data that is collected into a single unit that becomes a information that is interconnected and supports each other into an information which is beneficial for the recipient.

Objective: The purpose of this study was to design a COVID-19 patient information system using Visual Basic 2010 at Panghegar Health Center.

Methods: This method uses qualitative analysis with a descriptive approach for data collection, namely conducting observations, interview questions and answers, literature studies. and to design the design of COVID-19 patient information using Microsoft Visual Basic 2010 and the stages of system requirements, design, coding, testing using the Waterfall development method

Results: It is necessary to design a COVID-19 patient information system, software that is made to support the activity of reporting data on confirmed COVID-19 patients is easier to find and the COVID-19 patient data is inputted by the system.

Conclusion: The design of the COVID-19 patient information system uses the Visual Basic 2010 program and uses the waterfall method that has been created and designed regarding the identity data of confirmed COVID19 patients, clinical information of COVID-19 patients, monitoring information of confirmed COVID-19 patients, and reports of COVID-19 patient data.COVID-19 can make it easier for officers to input, process, and produce patient data seen in each village that is declared cured.

Keywords: COVID-19; Microsoft Visual Basic 2010; design.

*Correspondent Author : Sandy Mahendra Email : morissandy09@gmail.com

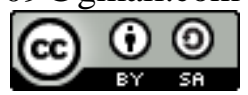

\section{PENDAHULUAN}

Coronavirus Disease 19 (COVID-19) merupakan penyakit yang disebabkan oleh Novel Coronavirus (2019-nCoV) atau yang kini dinamakan SARS-CoV-2 yang merupakan virus jenis baru yang belum pernah diidentifikasi sebelumnya pada manusia. Tanda dan gejala umum infeksi COVID-19 antara lain gejala gangguan pernapasan akut seperti demam, batuk dan sesak napas hingga pada kasus yang berat menyebabkan pneumonia, sindrom pernapasan akut, gagal ginjal dan bahkan kematian. Manifestasi klinisnya muncul dalam 2 hari hingga 14 hari setelah terjadi pajanan (Manurung et al., 2021). Hingga saat ini masih diyakini bahwa transmisi penularan COVID-19 adalah melalui droplet dan kontak langsung, kecuali bila ada tindakan medis yang memicu terjadinya aerosol (misalnya resusitasi jantung paru, pemeriksaan gigi seperti penggunaan scaler ultrasonik 
dan high speed air driven, pemeriksaan hidung dan tenggorokan, pemakaian nebulizer dan pengambilan swab) dimana dapat memicu terjadinya resiko penularan melalui airborne COVID-19 telah dinyatakan sebagai pandemi dunia oleh WHO (Organization, 2020).

Secara nasional melalui Keputusan Kepala Badan Nasional Penanggulangan Bencana Nomor 9A Tahun 2020 yang diperbarui melalui Keputusan nomor 13 A Tahun 2020 telah ditetapkan Status Keadaan Tertentu Darurat Bencana Wabah Penyakit Akibat Virus Corona di Indonesia (Fauzan, 2020). Selanjutnya, dengan memperhatikan eskalasi kasus dan perluasan wilayah terdampak, Pemerintah menerbitkan Peraturan Pemerintah Nomor 21 Tahun 2020 tentang Pembatasan Sosial Berskala Besar (PSBB) dalam Rangka Percepatan Penanganan COVID-19, serta Keputusan Presiden Nomor 11 Tahun 2020 tentang Penetapan Kedaruratan Kesehatan Masyarakat COVID-19, kemudian diperbaharui dengan Keputusan Presiden Nomor 12 Tahun 2020 tentang Penetapan Bencana Non Alam Penyebaran COVID-19 Sebagai Bencana Nasional. Puskesmas merupakan gardan terdepan dalam memutus mata rantai penularan COVID-19 karena berada di setiap kecamatan dan memiliki konsep wilayah.Di Puskesmas tersebut penambahan dan penyebaran kasus COVID-19 di Tiga kelurahan berlangsung begitu cepat dalam kondisi pandemi COVID-19 ini agar, mempermudah untuk mendata warga yang terkonfirmasi dan mempunyai gejala yang sudah diumumkan oleh WHO pada bulan September 2019 lalu (Kemekes, 2020).

Perancangan merupakan suatu proses dalam mendesain sistem baru yang dapat menyelesaikan masalah yang dihadapi (Darmawan \& Fauzi, 2015). Dimulai dari proses pengolahan data dari bahan mentah dari informasi yang dilakukan oleh seorang atau sekelompok orang yang akan menjadi masukan dari sebuah sistem informasi.

Selanjutnya merancang bentuk keluaran dari sebuah sistem tersebut. Sistem informasi merupakan data yang dikumpulkan menjadi satu kesatuan yang menjadi sebuah informasi yang saling berhubungan dan saling mendukung menjadi suatu informasi yang bermanfaat bagi penerimanya (Hartono, 2013).

Berdasarkan permasalahan di puskesmas yaitu Data pasien dari kelurahan masih disatukan dan belum terdata sesuai kelurahannya dan sulit mencari data pasien yang dituju dan mengakibatkan data pasien sebelumnya yang sudah melakukan isolasi mandiri dan dinyatakan sembuh, data pasien tersebut menjadi menyatu lagi dengan data pasien terkonfirmasi COVID-19 dan Form Pemantauan masih manual.Mempermudah pengumpulan data pasien terkonfirmasi COVID-19 Peneliti membuat perancangan sistem informasi pasien COVID-19 Menggunakan Visual Basic 2010 agar data pasien tersimpan setiap harinya perkembangan kondisi pasien yang sedang dipantau tersimpan ke data kelurahan dan terinput di sistem dan terlihat.

\section{METODE PENELITIAN}

Penelitian ini menggunakan metode analisis kualitatif dengan pendekatan deskriptif. Beberapa cara untuk mengumpulkan data yaitu melakukan observasi secara langsung pada objek yang akan diteliti yaitu di puskemas panghegar khusus nya pada pengolahan data pasien yang terkonfirmasi COVID-19 per-kelurahan, Melakukan wawancara Tanya jawab, wawancara yang dilakukan tidak terstruktur atau bebas dan hanya menanyakan garis besar permasalahan, Studi Kepustakaan yang dimaksud untuk menggambarkan data yang diperoleh dari lapangan penelitian dengan cara menguraikan dan menarik kesimpulan dari data apa adanya ditinjau dari berbagai aspek (Yuliana,2019). Hal ini guna memperoleh beberapa teori yang relevan dengan pokok permasalahan penelitian ini, sehingga dapat mendukung dalam pembuktian dan membantu memecahkan masalah dalam peneliti. Metode untuk mendesain menggunakan Visual Basic 2010 untuk membuat sistem perancangan informasi dan menggunakan metode waterfall (Kurniawan et al., 2020). 
Berikut ini tahapan yang dilakukan untuk mengembangkan sistem perangkat lunak menggunakan metode waterfall :

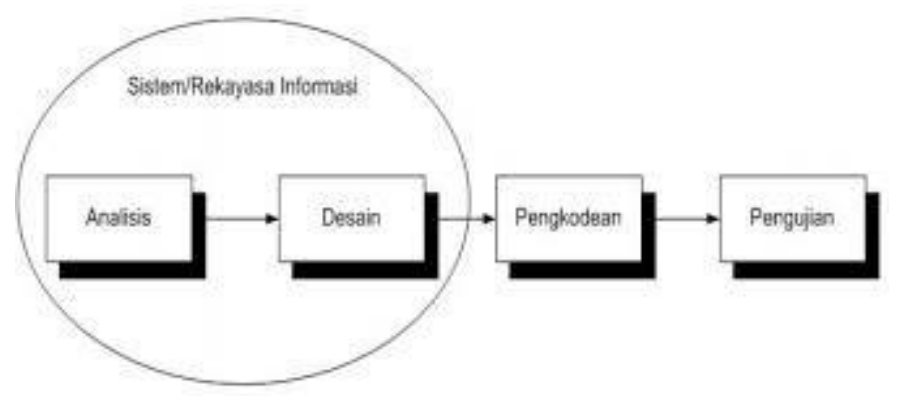

1. Analisis

Bertujuan untuk mencari berdasarkan kebutuhan pada sistem perangkat lunak. Dengan menganalisis apa saja yang diinputkan ke dalam sistem informasi ini.

2. Desain

Merupakan tahap perancangan sitem antarmuka yang akan di bangun seperti gambaran input atau output yang akan dibuat.

3. Pengkodean

Tahapan ini merupakan tahapan menerjemahkan desain ke dalam Bahasa pemograman. Tahapan pengkodean ini menggunakan Microsoft visual Basic 2010.

4. Pengujian

Tahapan pengujian ini dilakukan untuk myakinkan bahwa persyaratan perangkat yang telah dipenuhi dan meminimalisir adanya kesalahan .

\section{HASIL DAN PEMBAHASAN}

\section{A. Hasil Penelitian}

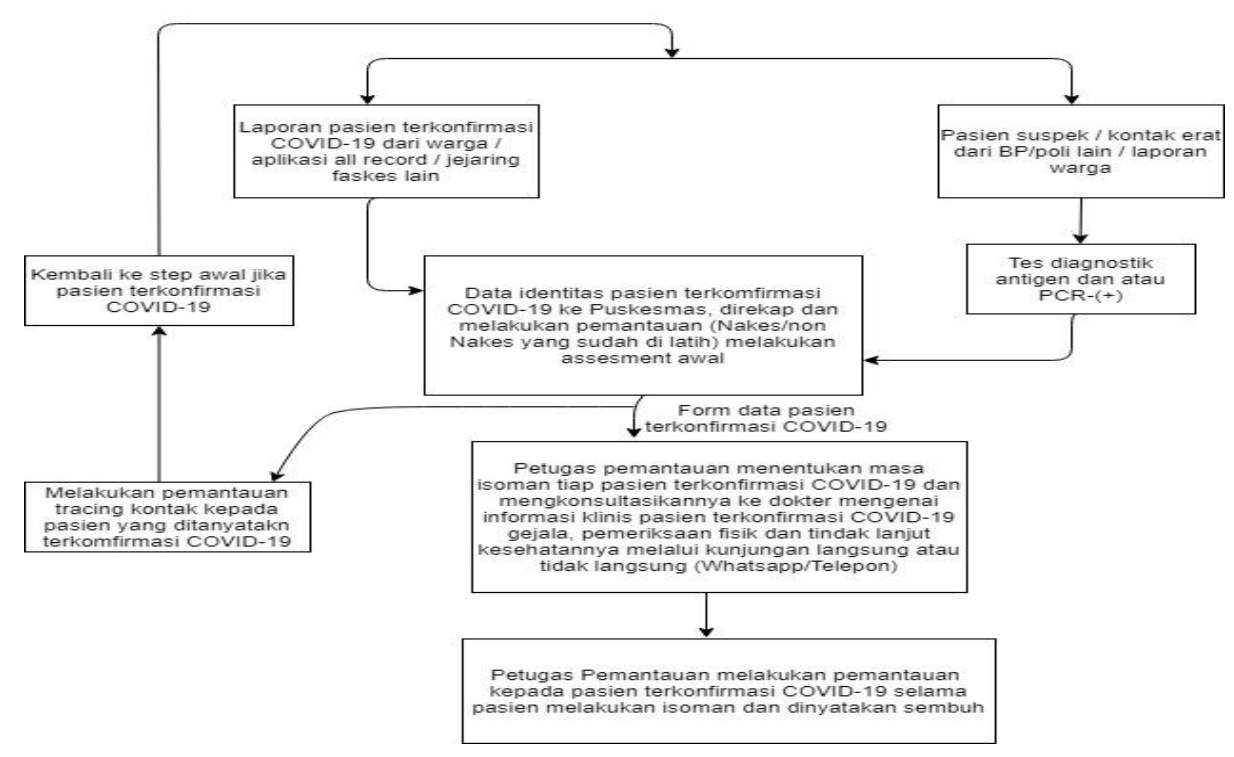

Gambar diatas adalah penerapan SOP Alur Pasien Terkonfirmasi COVID-19 di Puskesmas Panghegar ,berikut langkah- langkah penerapan SOP yang berjalan yaitu :

1. Laporan pasien terkomfirmasi COVID-19 dari warga, aplikasi all record dan jejaring Faskes lain. 
2. Pasien suspek /kontak erat dari BP,poli lain dan laporan dari warga melakukan tes diagnostik antigen atau melakukan tes antigen PCR untuk memastikan kondisinya bahwa kontak erat terkomfirkasi COVID-19 atau tidak.

3. Jika kondisi pasien pada saat melakukan tes antigen/PCR hasilnya Positif data tersebut direkap dan mulai melakukan pemantauan oleh petugas.

4. Petugas pemantauan menentukan masa isoman tiap pasien terkonfirmasi COVID-19 dan mengkonsultasikan ke dokter mengenai informasi klinis pasien terkomfirmasi COVID-19 seperti gejala yang diderita oleh pasien, pemeriksaan fisik dan tindak lanjut kesehatannya, melalui kunjungan langsung atau tidak langsung(melalui Whatsapp/Telepon).

5. Melakukan pemantauan tracing kontak kepada pasien yang dinyatakan terkonfirmasi COVID-19, melakukan pemantauan sampai pasien terkomfirmasi COVID-19 dinyatakan Sembuh dan diberi surat bebas pemantauan untuk di laporkan kepada $\mathrm{RT} / \mathrm{RW}$ setempat.

Karena form data pasien terkomfirmasi COVID-19 di Puskesmas Panghegar masih manual, data pasien COVID-19 tiap kelurahan masih menyatu belum terdata sesuai kelurahannya dan sulit mencari data pasien yang dituju, mengakibatkan data pasien sebelumnya yang sudah melakukan isolasi mandiri dan dinyatakan sembuh data pasien tersebut menjadi menyatu lagi dengan data pasien terkonfirmasi COVID-19.

Maka tujuan membuat perancangan sistem informasi pasien COVID-19 dapat mengolah data pasien terkomfirmasi COVID-19 yang diinput oleh petugas dari mulai identitas pasien COVID-19, informasi klinis pasien, informasi pemantauan disetiap harinya, dan laporan data pasien tiap kelurahan lebih mudah, lebih detail dan bisa di akses oleh petugas Puskesmas Panghegar. Langkah yang harus dilakukan oleh pasien jika terjangkit atau terkonfirmasi COVID-19 yaitu melapor kepada RT/RW setempat bahwa terjangkit COVID-19, menyerahkan berkas atau dokumen seperti hasil Swab, KTP, Kartu keluarga dan identitas lainnya melalui whaatsapp atau G-Form yang sudah di sediakan agar data tersebut diserahkan kepada pihak puskesmas agar melakukan pemantauan oleh petugas terhadap pasien terkonfirmasi COVID-19 (Negari \& Eryando, 2021).

1. Langkah pertama untuk menggunakan aplikasi yang dibuat Sebelum menginput data pasien terkonfirmasi COVID-19 yaitu mengisi username dan password.

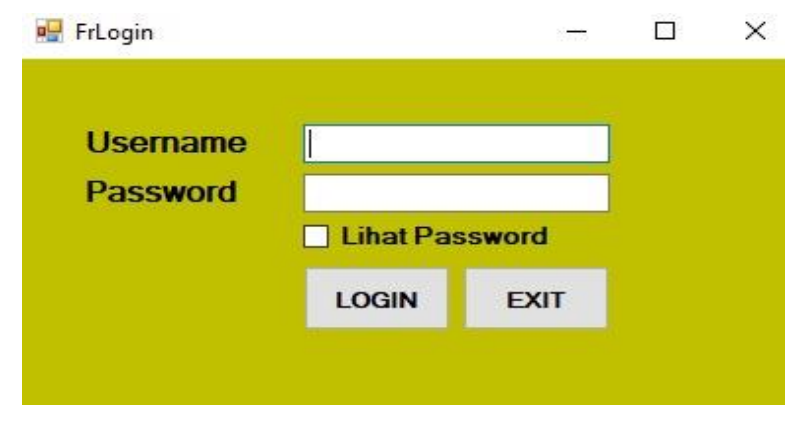

2. Langkah ke dua mengisi data pasien terkonfirmasi COVID-19 data tersebut adalah laporan dari pihak RT/RW setempat yang sudah di laporkan kepada pihak puskesmas. 


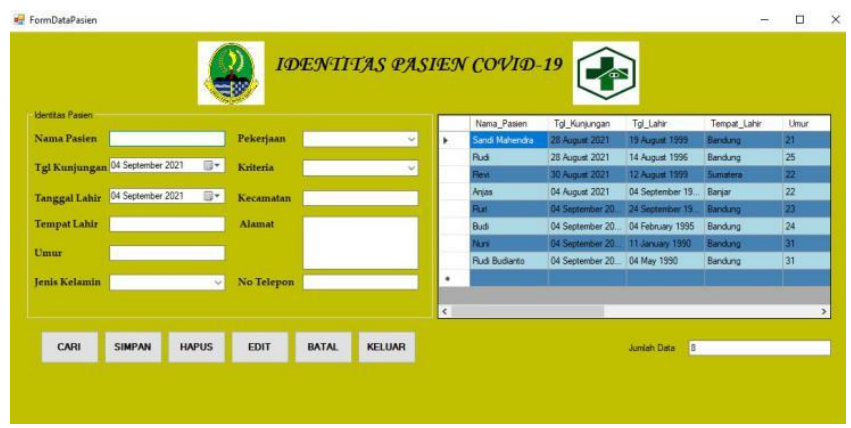

3. Langkah ke tiga mengisi keluhan yang diderita oleh pasien sebelum melakukan pemantauan.

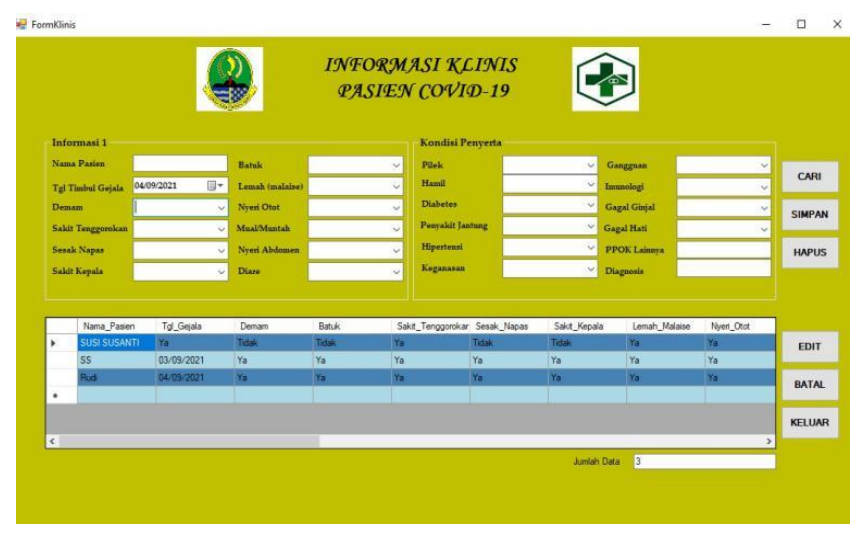

4. Melakukan pemantauan pasien terkonfirmasi COVID-19 pada saat isolasi mandiri 14 hari maupun lebih.

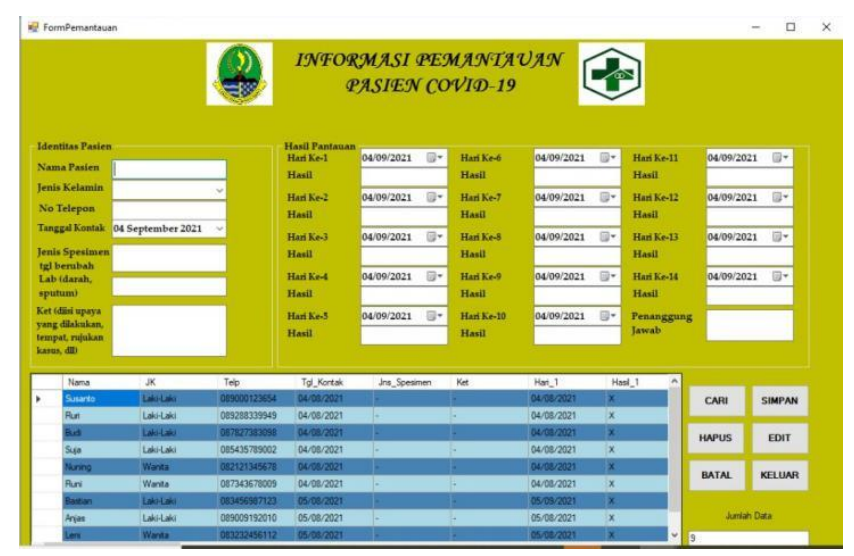

5. Hasil data pasien terkonfirmasi COVID-19 yang sudah terpantau. 


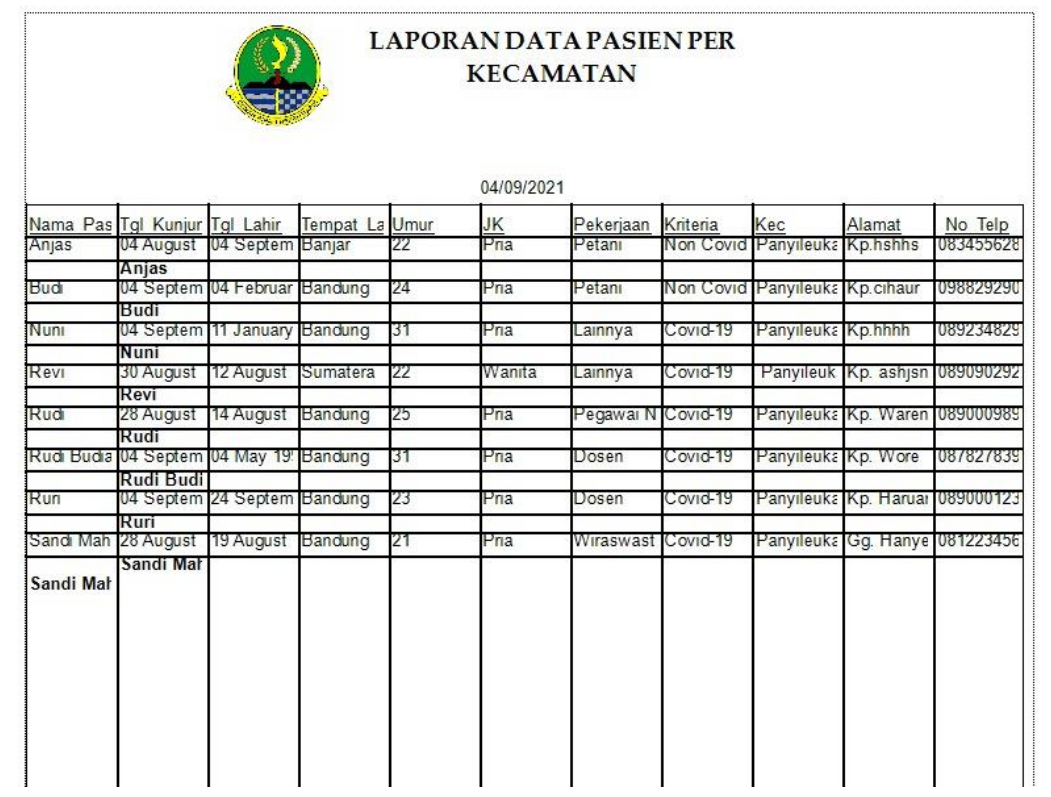

6. Grafik Pasien COVID-19.

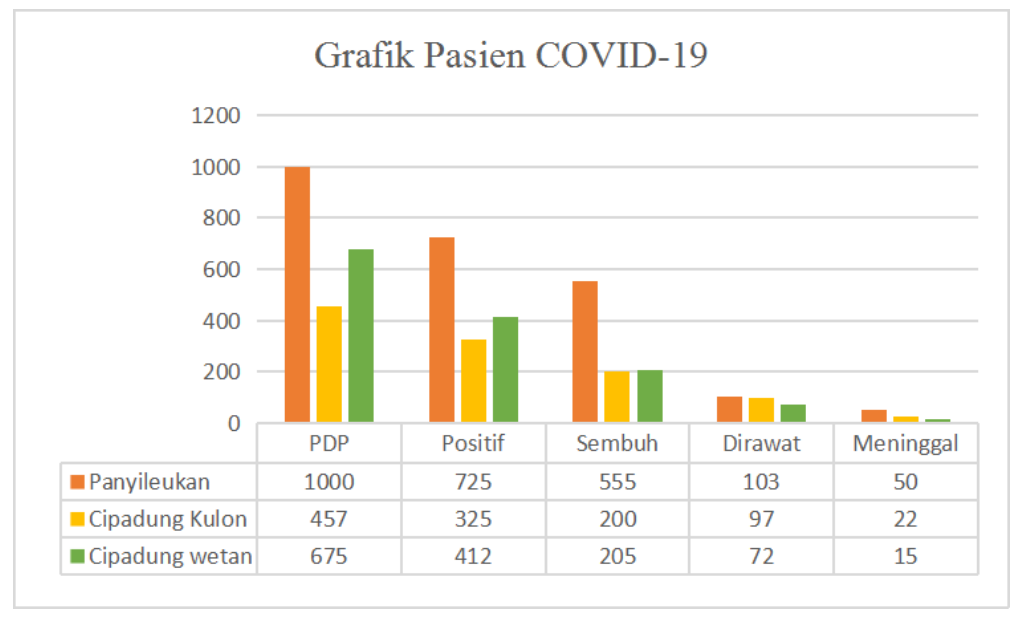

\section{B. Pembahasan}

Hasil Program Tersebut dibuat oleh penulis dari mulai alur penginputan data pasien tiap kelurahan terkonfirmasi COVID-19, DFD level-1 proses1.0, diagram konteks, DFD level- 0. dan grafik batang

1. Alur penginputan data pasien tiap kelurahan terkonfirmasi COVID-19 


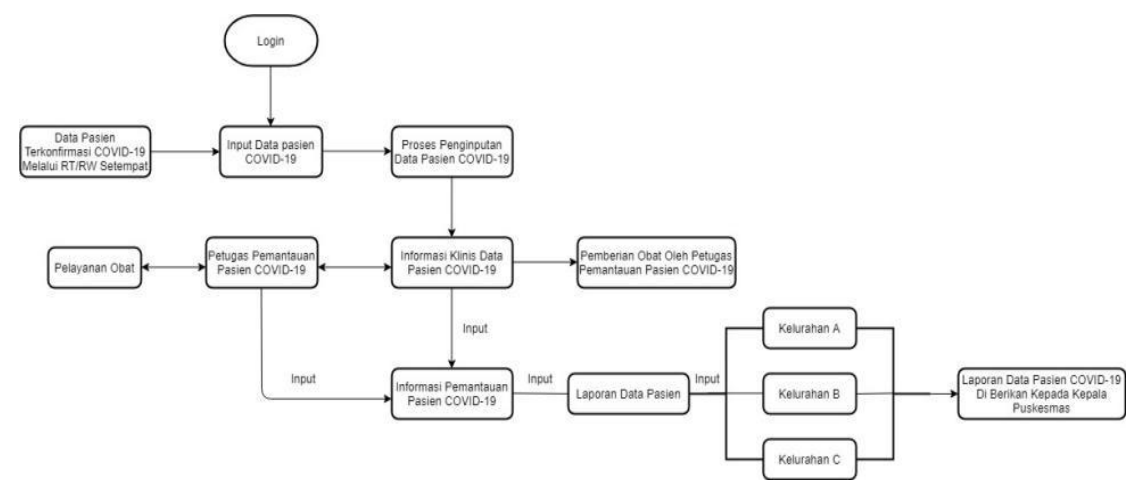

2. DFD merupakan alat yang berfungsi merencanakan sebuah sistem yang terhubung ke alur data dengan menggunakan sebuah konsep dekomposisi sehingga bisa dimanfaatkan untuk menggambarkan sebuah analisa maupun menggambarkan sebuah rancangan sistem. berikut gambar rancangan sistem DFD level-1 proses 1.0 (Muslihudin, 2016).

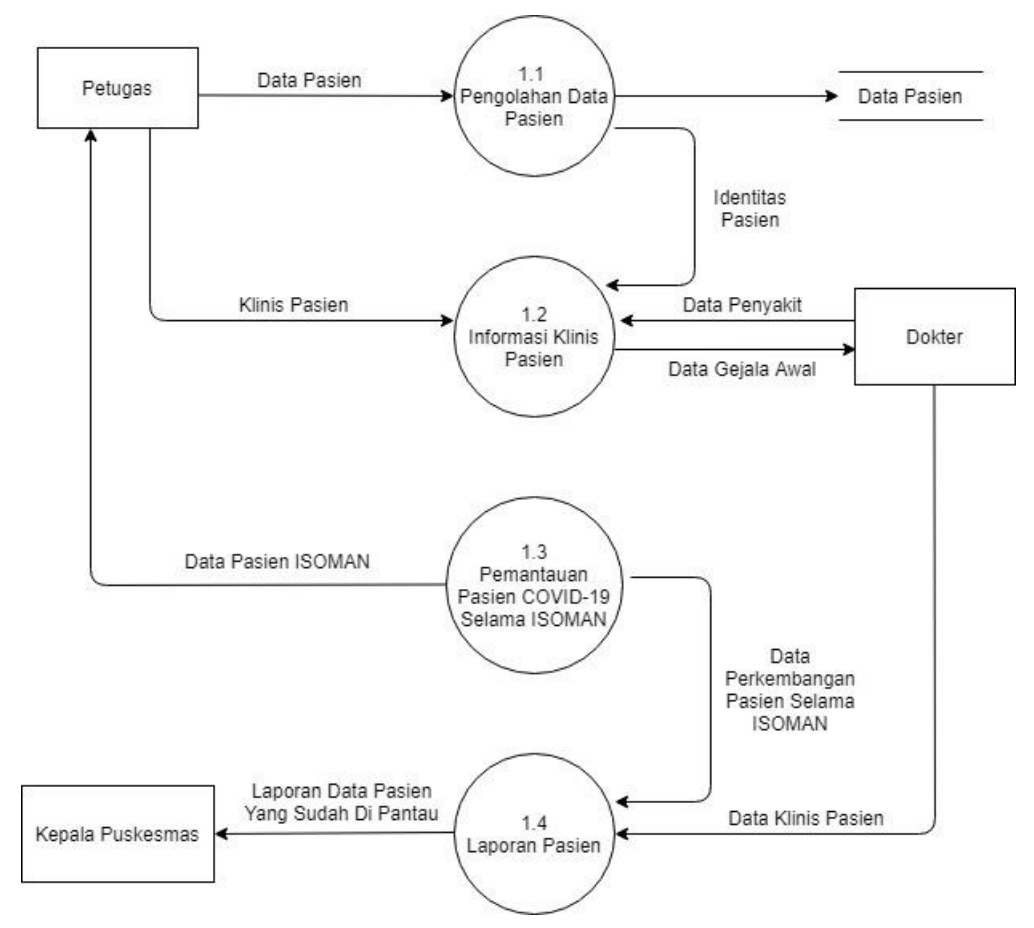

3. Program tersebut menggunakan sistem diagram konteks, dimana terdapat empat buah entitas yang saling berhubungan yang terdiri dari, data pasien terkonfirmasi COVID-19 yang di laporkan kepada pihak puskesmas melalui RT/RW setempat dan data itu di input oleh petugas dan diserahkan kepada kepala puskesmas 


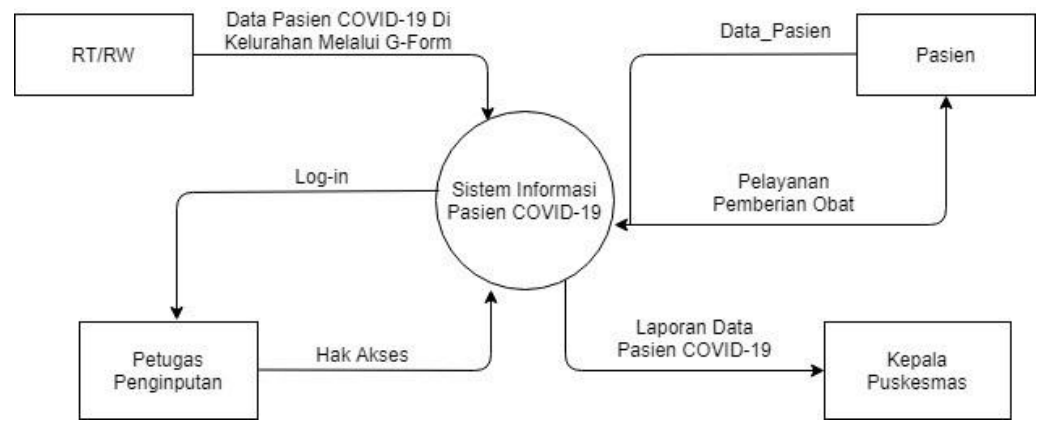

4. DFD-level 0 ini menggambarkan sistem secara keseluruhan proses yang dilakukan adalah menginputkan data pasien terkonfirmasi COVID-19 kepada sistem yang dibuat.

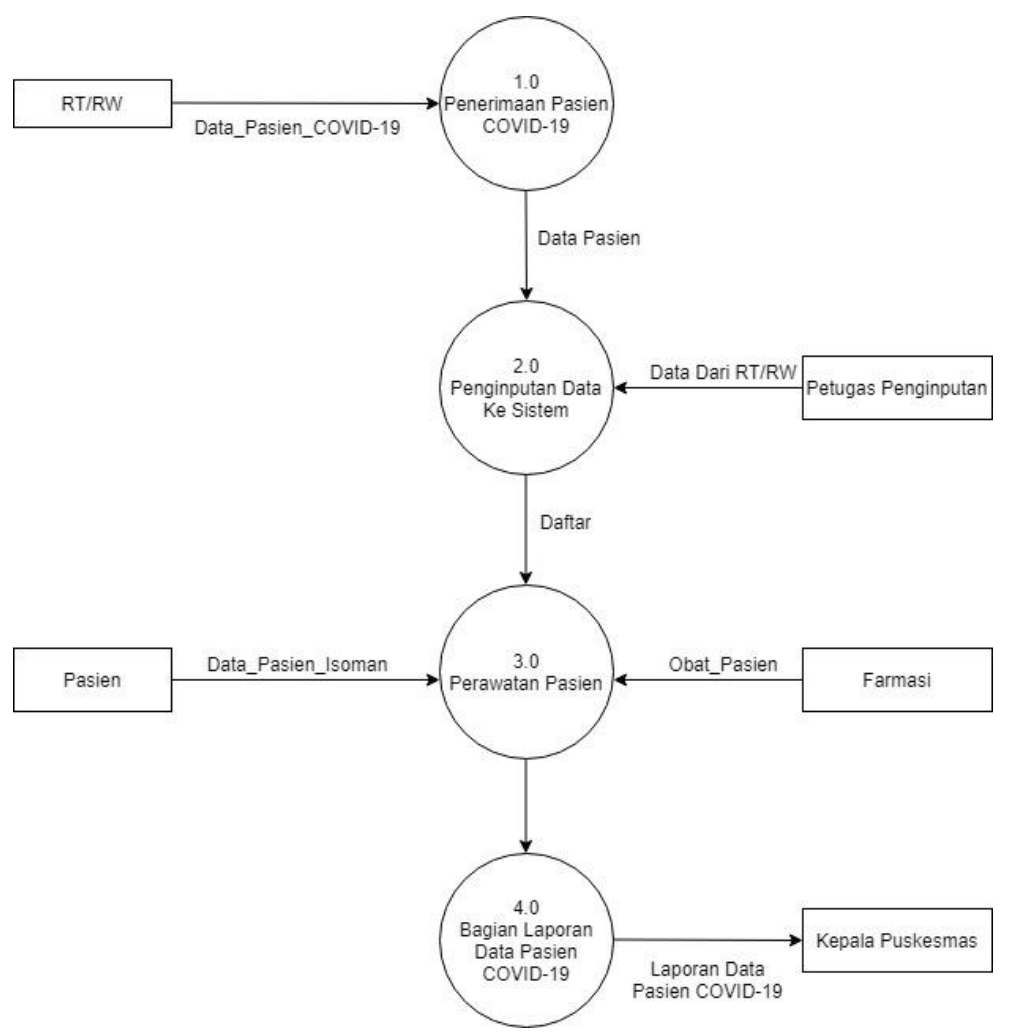

5. Grafik Batang adalah jenis grafik yang menggambarkan beberapa data dalam bentung batang, yang terdiri dari data pasien di kelurahan cipadungkulon, cipadungwetan, panyileukan.

\section{KESIMPULAN}

Dengan adanya perancangan system informasi pasien COVID-19 yang dibuat memakai program Visual Basic 2010 dan tahap kebutuhan system, desain ,koding, pengujian menggunakan metode waterfall yang sudah dibuat dan dirancang mengenai data identitas pasien terkomfirmasi COVID-19, informasi klinis pasien COVID-19, informasi pemantauan pasien terkomfirmasi COVID-19, dan laporan data pasien COVID-19 tersebut tersusun dengan rapih sehingga mempermudah petugas untuk mencari data pasien COVID-19 yang sudah di pantau atau belum terpantau. Pada saat mencoba program yang sudah dirancang ini 
hasilnya tidak ada masalah pada system yang dibuat dan dapat di terapkan untuk proses pengumpulan data, lalu di olah hinggal pada proses penyimpanan data pasien COVID-19

\section{BIBLIOGRAFI}

Darmawan, D., \& Fauzi, K. N. (2015). Sistem Informasi Manajemen, edisi 3. Bandung: Remaja Rosdakarya.

Fauzan, M. (2020). Laporan Praktik Kerja Lapangan Pada Badan Nasional Penanggulangan Bencana.

Hartono, B. (2013). Sistem Informasi Manajemen Berbasis Komputer.

Kemekes, R. (2020). Petunjuk Teknis Pelayanan Puskesmas Pada Masa Pandemi COVID19. Kemenkes RI.

Kurniawan, H., Apriliah, W., Kurniawan, I., \& Firmansyah, D. (2020). Penerapan Metode Waterfall Dalam Perancangan Sistem Informasi Penggajian Pada Smk Bina Karya Karawang. Jurnal Interkom: Jurnal Publikasi Ilmiah Bidang Teknologi Informasi Dan Komunikasi, 14(4), 13-23.

Manurung, J., Munthe, S. A., \& Bangun, H. A. (2021). Pelatihan Relawan Pos Gabungan Pencegahan COVID-19 Kepada Utusan Kecamatan Dari Wilayah Medan-BinjaiDeliserdang (Mebidang) Tahun 2020. Jurnal Abdimas Mutiara, 2(2), 109-118.

Muslihudin, M. (2016). Analisis Dan Perancangan Sistem Informasi Menggunakan Model Terstruktur Dan UML. Penerbit Andi.

Negari, N., \& Eryando, T. (2021). Analisis Penerimaan Sistem Informasi Pencatatan dan Pelaporan Kasus COVID-19 (Aplikasi Silacak Versi 1.2. 5) Menggunakan Technology Acceptance Model (TAM) di UPT Puskesmas Cipadung Kota Bandung. Jurnal Biostatistik, Kependudukan, Dan Informatika Kesehatan, 1(3), 160-176.

Organization, W. H. (2020). Infection prevention and control health-care facility response for COVID-19: a module from the suite of health service capacity assessments in the context of the COVID-19 pandemic: interim guidance, 20 October 2020. World Health Organization.

Yuliana, S. (2019). Bimbingan konseling individu dalam mencegah kenakalan remaja: Penelitian di MA YAPATA Al-Jawami Cileunyi Bandung. UIN Sunan Gunung Djati Bandung.

(C) 2021 by the authors. Submitted for possible open access publication under the

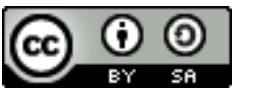
terms and conditions of the Creative Commons Attribution (CC BY SA) license (https://creativecommons.org/licenses/by-sa/4.0/). 